\title{
Selection of specific cell wall antigen for rapid detection of fish pathogenic Vibrio parahaemolyticus by enzyme immunoassay
}

\author{
P. S. SHYNE ANAND*, K. S. SOBHANA, K. C. GEORGE AND R. PAUL RAJ \\ ICAR-Central Marine Fisheries Research Institute, Kochi - 682 018, Kerala, India \\ *ICAR-Central Institute of Brackishwater Aquaculture, 75, Santhome High Road, Raja Annamalai Puram \\ Chennai - 600 028, Tamil Nadu, India \\ e-mail: shyne.anand@gmail.com
}

\begin{abstract}
An enzyme linked immunosorbant assay (ELISA) was developed, using polyclonal antibodies against a specific cell surface protein of Vibrio parahaemolyticus, for rapid detection of the organism. Nine virulent strains and one type strain of V. parahaemolyticus, one strain each of Vibrio vulnificus and Vibrio alginolyticus were used for the study. Cell surface proteins were extracted from all the strains and were analysed by SDS PAGE. One distinct band with molecular weight of $34 \mathrm{kDa}$, abundant in all the $V$. parahaemolyticus strains and lacks in other Vibrio species, was selected as cell wall antigen for immunisation. Polyclonal antibodies were raised against the selected $34 \mathrm{kDa}$ protein of $V$. parahaemolyticus after preparative electrophoresis. An indirect plate ELISA was developed using this antiserum for detection of crude cell surface protein as well as whole cells of $V$. parahaemolyticus. All the 9 virulent strains and one type strain of V. parahaemolyticus tested, produced positive results, using the ELISA technique. To assess the specificity of the polyclonal serum, cross reaction studies with other Vibrio species such as $V$. vulnificus and $V$. alginolyticus were conducted by indirect plate ELISA. The results have clearly shown that antibodies directed against $34 \mathrm{kDa}$ cell surface protein can be used for specific detection of fish pathogenic V. parahaemolyticus.
\end{abstract}

Keywords: Enzyme linked immunosorbant assay (ELISA), Fish pathogen, Polyclonal antiserum, Vibrio parahaemolyticus

\section{Introduction}

Mariculture has rapidly expanded in the recent decades in many Asian countries with better economic return over investment. However, fish diseases of bacterial origin have been one of the most important factors leading to economic loss since the beginning of mariculture (Kumar et al., 2007; Sobhana, 2009). Vibriosis is one of the major bacterial diseases that affect marine finfish, with the major etiological agents being Vibrio harveyi, Vibrio alginolyticus and Vibrio parahaemolyticus (Harikrishnan et al., 2010; Krupesha Sharma et al., 2012). Species under the genus Vibrio are Gram - negative bacteria found in fresh, estuarine and marine ecosystems and exist as part of normal microbiota or as primary or secondary pathogens (Austin and Austin, 2007). V. parahaemolyticus is one of the major Vibrio species isolated from vibriosis infected marine fishes (Sudheesh and Xu, 2001; Liao et al., 2004; Harikrishnan et al., 2011). This Vibrio species has been reported to cause diseases in cultured groupers in Thailand (Danayadol, 1999), Malaysia (Najiah et al., 2003), China (Li et al., 2010) and Vietnam (Do et al., 2008; Nguyen and Nguyen, 2008) resulting in high mortalities and economic losses.
For diagnosis of bacterial diseases, conventional methods of isolation and identification like biochemical methods are most commonly used, but these are time consuming and laborious. The use of nucleic acid probes and PCR for detection of microbial pathogens are gaining importance, but these need sophisticated equipment and are not suitable for large scale screening of samples (Tyagi et al., 2009; Rosec et al., 2009). Development of rapid and sensitive immunodiagnostic techniques for important bacterial pathogens, based on polyclonal/monoclonal antibodies, can help in timely diagnosis of diseases and to adopt more scientific health management measures (Chi et al., 2007; Diasda and Tambourgi, 2010).

Among the different methods, which may be used for rapid detection of pathogenic bacteria, immunological techniques are promising, because of their sensitivity and rapidity (Qian et al., 2008; Thuy et al., 2013). However it is necessary, to select appropriate antigens for developing immunoassays, in order to avoid cross reactions. For Gram negative bacteria, the selection of appropriate antigen is somewhat easier, as different proteins from the outer membranes are known to be common antigens for a genus or a species (Fofstra and Dankert, 1979; Inoue et al., 1995; Ningqiu et al., 2008). The outer membranes of 
Gram negative bacteria contain several distinct proteins, with molecular weights in the range of 30 to $40 \mathrm{kDa}$ (Manning et al., 1982; Li et al., 2010). These proteins are sometimes species-specific and have high antigenicity (Kabir, 1986; Seltman and Holst, 2002; Mao et al., 2007). Therefore, antibodies against these specific proteins can be explored as tools for rapid identification of these bacteria (Swain and Nayak, 2003).

A great deal of interest has been developed towards exploring the possibility of evolving enzyme immunoassays, based on specific cell surface proteins, for detection of bacterial pathogens (Bhunia and Johnson, 1992; Chen and Chang, 1996; Swain et al., 2001; Tully et al., 2006). Keeping this in view, the present study was undertaken to develop an indirect enzyme linked immunosorbent assay, using polyclonal rabbit antiserum raised against a specific cell wall antigen (34 kDa) for detection of fish pathogen, V. parahaemolyticus.

\section{Materials and methods}

Test strains

Nine fish pathogenic strains of $V$. parahaemolyticus (VP1; VP2; VP3; VP4; VP5; VP6; VP7; VP8 and VP9); one strain each of $V$. vulnificus (VV) and $V$. alginolyticus (VA), originally isolated from vibriosis affected groupers (Epinephelus malabaricus and Epinephelus coioides) from different disease incidences, were used for the study. The bacterial strains were isolated from diseased groupers from the experimental tanks, broodstock facilities at Marine Hatchery of the Central Marine Fisheires Research Institute (CMFRI) at Cochin Fisheries Harbour, Kochi and at the Mandapam Regional Centre of CMFRI at Mandapam. All the strains used were tested for virulence in juveniles of E. malabaricus. One type strain of V. parahaemolyticus (MTCC 451), procured from Institute for microbial technology (IMTECH), Chandigarh, India was also used.

\section{Phenotypic and biochemical characteristics of test strains}

All the test strains used were reconfirmed for their phenotypic and biochemical characteristics. The strains were characterised based on their growth on selective media [Thiosulfate citrate bile salts sucrose (TCBS) agar, Difco], colony characteristics, Gram staining, motility and a series of biochemical tests such as amino acid decarboxylase test (Mac Faddin, 1980), sugar fermentation test (West and Colwell, 1984), growth in salt tryptone broth to study halophilism, growth at $43^{\circ} \mathrm{C}$, cytochrome oxidase test (Holding and Collee, 1971), nitrate reduction test (Crosby, 1967), catalase test, methyl red and Voges Proskaeur test (Lee et al., 1979), indole production, triple sugar iron agar (TSI) and Kligler iron agar (KIA) reactions, oxidation/fermentation $(\mathrm{O} / \mathrm{F})$ test, urease test, gelatinase test (Smith and Goodner, 1958), citrate utilisation test, O-nitrophenyl $\beta$-D galactopyranosidase, ONPG ( $\beta$-galactosidase) test (Paik, 1980) and sensitivity to $0 / 129$ discs. All media used for the tests contained $2.5 \% \mathrm{NaCl}(\mathrm{W} / \mathrm{V})$. The isolates were then identified to species level according to Bauman and Schubert (1984).

Kanagawa reaction to test haemolytic activity

( $\beta$ - haemolysis)

Kanagawa reaction was performed on Wagatsuma agar (Wagatsuma, 1967). Haemolytic activity of the bacterial strains were tested by spot inoculating the strains onto each freshly prepared and dried Wagatsuma agar containing a suspension of mammalian/fish red blood cells. The plates were incubated for $18 \pm 2 \mathrm{~h}$ at $37^{\circ} \mathrm{C}$ and were observed for presence of zone of haemolysis around the colony.

Extraction and purification of cell surface proteins (CSP)

Cell surface proteins were extracted from all the 10 strains of $V$. parahaemolyticus, including the type strain, MTCC 451 and one strain each of $V$. vulnificus (VV) and $V$. alginolyticus (VA). Extraction of outer membrane proteins from the above mentioned test strains was carried out following the method described by Chen and Chang (1996) with modifications. Briefly, the organisms grown overnight on nutrient agar (NA) slants were harvested in $2 \mathrm{ml}$ phosphate buffered saline (PBS, $\mathrm{pH}$ 7.2) and inoculated in tryptone soya broth (TSB) for 18-24 h at room temperature. The cells were pelletised by centrifugation at 5,000 $\mathrm{g}$ for $20 \mathrm{~min}$ at $4^{\circ} \mathrm{C}$ and then washed three times with PBS (pH 7.2). The resultant pellet was suspended in $10 \mathrm{ml}$ PBS containing 1\% sodium dodecyl sulphate (SDS) and heated in a water bath maintained at $70^{\circ} \mathrm{C}$ for $2 \mathrm{~h}$ with occasional shaking. The bacterial cells were centrifuged at $10,000 \mathrm{~g}$ for $20 \mathrm{~min}$ at $4^{\circ} \mathrm{C}$ in a refrigerated centrifuge. The supernatant containing SDS extracted cell surface proteins was collected and stored at $-20^{\circ} \mathrm{C}$, till further use. The crude cell surface extracts were dialysed against PBS ( $\mathrm{pH}$ 7.2) using dialysis tubing (Sigma) having a molecular weight cut off $(\mathrm{MWCO})>12 \mathrm{kDa}$. The protein content of the crude cell surface proteins was determined following dialysis, from each test strain using the method of Lowry et al. (1951).

\section{SDS PAGE analysis of crude cell surface protein}

The extracted cell surface proteins were analysed by SDS PAGE on $12.5 \%(\mathrm{w} / \mathrm{v})$ acrylamide resolving gel and 4\% stacking gel (acrylamide $30 \%$ and bisacrylamide $8 \%$ ) containing $0.1 \%$ SDS as described by Laemmli (1970) using a compact dual mini vertical slab gel electrophoresis unit (Scie-Plas, UK). The samples were mixed with 
2x Laemmli sample buffer in a proportion of 1:2 and subsequently heated at $95^{\circ} \mathrm{C}$ for 5 min before loading in to the wells. Approximately $200 \mu \mathrm{g}$ of proteins were loaded to each lane of the gels. Standard molecular weight markers (Genei, Bangalore) were run parallel along with sample proteins, to determine the relative molecular weights of the polypeptides. After electrophoretic run, the protein bands were visualised by staining with Coomassie Brilliant blue-R250.

\section{Antiserum against purified cell surface proteins}

The $34 \mathrm{kDa}$ cell surface antigen of $V$. parahaemolyticus (VP6) was purified by preparative SDS PAGE on $3 \mathrm{~mm}$ thick gels. After the electrophoretic run, protein bands were rapidly visualised by staining with $4 \mathrm{M}$ sodium acetate solution for 60 to $80 \mathrm{~min}$ with shaking (Higgins and Dahmus, 1979). The protein bands got visualised as clear bands on the milky white background. After appropriate visualisation, the band corresponding to molecular weight, $34 \mathrm{kDa}$ was excised with a scalpel and immediately washed thrice ( 2 min each) in deionised water with shaking.

The polyacrylamide gel strip containing the $34 \mathrm{kDa}$ protein (approximately $5 \mathrm{mg}$ ) was cut in to small pieces and then crushed in to fine particles using a micro-pestle in an eppendorf vial. The fine gel particles were suspended in PBS (2-3 ml) and emulsified with an equal volume of Freund's incomplete adjuvant (FIA). Two milliliters of the emulsified antigen was injected subcutaneously at 4 to 6 dorsal sites on the back of a New Zealand white rabbit (average weight of $2 \mathrm{~kg}$ ). Three booster doses were given at 3 weeks intervals in a similar way. Ten days following the $3^{\text {rd }}$ booster, blood was collected by ear vein puncture using sterile 26-gauge needle and syringe. Blood was allowed to clot and serum was separated by centrifugation at $3000 \mathrm{~g}$ for $10 \mathrm{~min}$. Control/negative serum was also raised by injecting a New Zealand white rabbit (average weight of $2 \mathrm{~kg}$ ) with $1 \mathrm{ml}$ PBS emulsified with an equal quantity of FIA. The sera were de complemented at $56^{\circ} \mathrm{C}$ for $30 \mathrm{~min}$ in a water bath and stored at $-20^{\circ} \mathrm{C}$ until further use.

\section{Enzyme immunoassay (Indirect plate ELISA)}

An indirect plate ELISA test was developed to detect the cell surface proteins and heat killed whole cells of $V$. parahaemolyticus, using antiserum raised against the specific $34 \mathrm{kDa}$ outer membrane protein. The ELISA used for the detection was as per the methods described by Cheng and Chang (1996) with slight modifications.

The ELISA plates (Griener, Germany) were coated with $100 \mu \mathrm{l}$ per well of coating buffer (carbonate bicarbonate buffer, $\mathrm{pH}$ 9.6) containing cell surface protein extracted from VP6 as an antigen at 10, 20, 40, 60, 80 and $100 \mu \mathrm{g} \mathrm{ml}^{-1}$. The plates were incubated overnight at $4^{\circ} \mathrm{C}$ and subsequently washed thrice with PBS-T (PBS containing $0.05 \%$ Tween $20, \mathrm{pH} 7.4$ ). The unsaturated sites of the plates were blocked by adding $100 \mu \mathrm{l}$ per well of $1 \%$ BSA in PBS-T and incubated at $37^{\circ} \mathrm{C}$ for $1 \mathrm{~h}$. The plates were washed thrice with PBS-T. Dilutions ranging from 1:100 to $1: 6400$ of the hyperimmune antiserum raised in rabbit against $34 \mathrm{kDa}$ protein were added to the wells $(100 \mu \mathrm{l}$ per well) in duplicate set. Similar dilutions of negative serum were also added. The plates were incubated at $37^{\circ} \mathrm{C}$ for $2 \mathrm{~h}$ and then washed thrice with PBS-T. Subsequently, goat anti-rabbit horseradish peroxidase (HRPO) conjugate (Genei, Bangalore), diluted with PBS-T in the ratio1:2000 was added $(100 \mu \mathrm{l})$. The plates were incubated at $37^{\circ} \mathrm{C}$ for $1 \mathrm{~h}$ and then washed thrice with PBS-T. Subsequently $100 \mu \mathrm{l}$ of $3,3,5,5$ tetramethyl benzidine (TMB) substrate (Genei, Bangalore) solution was added and then incubated for $10 \mathrm{~min}$ in the dark. The reaction was stopped by adding $100 \mu \mathrm{l}$ per well of $2 \mathrm{~N} \mathrm{H}_{2} \mathrm{SO}_{4}$ and colour development was measured at $450 \mathrm{~nm}$ in a microplate reader (Cary 50, Varian). The positive to negative ratios of more than 2 was considered positive.

The suitability of the indirect plate ELISA was also studied for the detection of whole cells of $V$. parahaemolyticus by standardising the indirect ELISA separately using various concentrations $\left(10^{3}\right.$ to $10^{9}$ cells ml-1) of heat killed $\left(80^{\circ} \mathrm{C}\right.$ for $10 \mathrm{~min}$ ) cells of $V$. parahaemolyticus as antigen for coating the plates (100 per $\mu$ l per well).

\section{Cross reaction studies}

The polyclonal antiserum against $34 \mathrm{kDa}$ protein was tested for cross reaction with $V$. alginolyticus and V. vulnificus strains by indirect plate ELISA. Heat killed $\left(80^{\circ} \mathrm{C}\right.$ for $\left.10 \mathrm{~min}\right)$ cells of these strains were suspended in coating buffer (carbonate bicarbonate buffer, $\mathrm{pH}$ 9.6) at a cell density of $10^{6}$ cells $\mathrm{ml}^{-1}$ and indirect plate ELISA was performed, as described earlier, using antsera raised against $34 \mathrm{kDa}$ cell surface protein of $V$. parahaemolyticus at a dilution of 1: 3200 .

\section{Results}

All the 9 strains and one type strain of $V$. parahaemolyticus (MTCC 451) gave typical reactions as per Bauman and Schubert (1984). They were Gram negative motile short rods, oxidase and catalase positive, producing green colonies on TCBS agar. In addition, they were resistant to the vibriostatic agent $0 / 129$ at $10 \mathrm{mg}$ and sensitive at $150 \mathrm{mg}$ concentration. All the strains showed growth in tryptone broth, supplemented with 3, 6 and $8 \%$ $(\mathrm{w} / \mathrm{v}) \mathrm{NaCl}$ and did not grow at 0 and $10 \%$ (w/v) $\mathrm{NaCl}$. All the strains of $V$. parahaemolyticus were negative for arginine while positive for lysine and ornithine 
decarboxylation. They were fermentative for arabinose, dextrose and mannitol without gas production, while non-fementative for sucrose, cellobiose, inositol, salicine and lactose. The strains were positive for gelatinase, urease and nitrate reduction tests and negative for ONPG test. All the test strains and the MTCC reference strain of $V$. parahaemolyticus gave negative reaction for haemolytic activity on Wagatsuma agar, indicating that they were all Kanagawa negative.

The electrophoretic profiles obtained after the SDS PAGE analysis of cell surface protein patterns of test strains showed several distinct protein bands with molecular weight in the range of 30 to $97 \mathrm{kDa}$ (Fig. 1a, lanes 2, 3, 4, 6 and Fig. 1b, lanes 1 to 6). Outer membrane protein pattern of all the $V$. parahaemolyticus test strains were identical, with 5 to 6 major bands having molecular weights of $34 \mathrm{kDa}, 36 \mathrm{kDa}, 37 \mathrm{kDa}, 55 \mathrm{kDa}, 75 \mathrm{kDa}$ and $93 \mathrm{kDa}$. The outer membrane protein pattern of the type strain of $V$. parahaemolyticus (MTCC 451) were

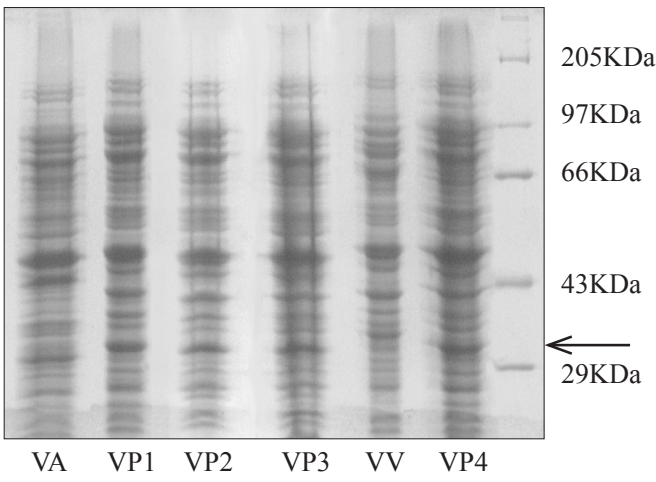

(a) and specificity, the $34 \mathrm{kDa}$ protein was selected as antigen for immunisation to develop polyclonal antiserum.

The extraction of cell surface antigens with $1 \%$ SDS was effective in solubilising the cell surface proteins and highly reproducible, showing similar banding patterns whenever repeated. The protein bands got visualised as clear bands on the milky white background (Fig. 2) in the preparative SDS PAGE gel, by staining with $4 \mathrm{M}$ sodium acetate solution. Antiserum was raised against cell surface protein having molecular weight of $34 \mathrm{kDa}$, which was found to be common in all $V$. parahaemolyticus isolates and not present in other vibrios. Immunisation of rabbits was accomplished by inoculation of protein along with FIA, after excising the specific molecular weight bands directly from preparative SDS PAGE gels. This method of immunisation, using proteins in PAGE, was found to be effective for production of antisera and after 3 boosters good titer was obtained.

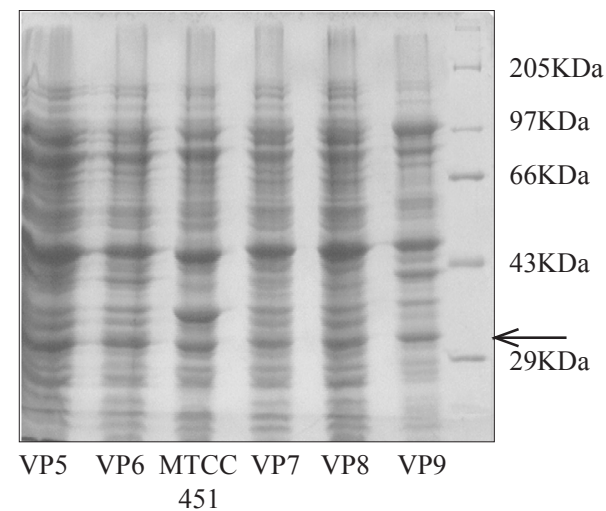

(b)

Fig. 1. SDS PAGE profile of the cell surface protein of the test strains stained by Coomassie Brilliant blue-R250 1a: VP1, VP2, VP3 and VP4 - V. parahaemolyticus test strains; VA - V. alginolyticus; VV - V. vulnificus; 1b: VP5, VP6, VP7, VP8 and VP9 - V. parahaemolyticus test strains; MTCC 451 - V. parahaemolyticus type strain (Arrow - 34 KDa protein band)

also quite similar, but with the $37 \mathrm{kDa}$ band being very prominent (Fig. 1b, lane 3), which was not so prominent in other 9 strains of $V$. parahaemolyticus. The outer membrane proteins of the two other closely related Vibrio species viz., $V$. alginolyticus and $V$. vulnificus are also shown in Fig. 1a (lanes 1 and 5 respectively). However, the patterns were quite different from those of $V$. parahaemolyticus. The major protein band of $55 \mathrm{kDa}$ was found to be common in all the three Vibrio species i.e., V. parahaemolyticus, $V$. aliginolyticus and $V$. vulnificus.

One distinct band (Fig. 1a, indicated with arrows) with apparent molecular weight of $34 \mathrm{kDa}$ was abundant in all the $V$. parahaemolyticus strains and were not observed in the other two Vibrio species analysed. Due to high concentration

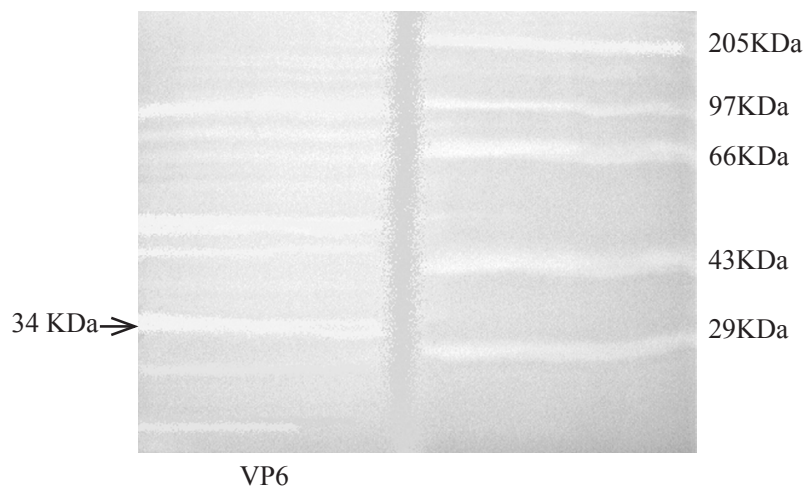

Fig. 2. Preparative SDS PAGE profile of the cell surface protein of $V$. parahaemolyticus (VP6) stained with 4 M sodium acetate (Arrow - $34 \mathrm{KDa}$ protein band of VP6) 
ELISA titer (OD values at $450 \mathrm{~nm}$ ) for different concentrations of crude cell surface proteins of $V$. parahaemolyticus at various dilutions of the antiserum raised against the $34 \mathrm{kDa}$ cell surface protein are given in Table 1. The positive to negative ratios of more than 2 were only considered. Accordingly, even the lowest concentration of $10 \mu \mathrm{g}$ cell surface protein used for testing, gave positive reaction at a maximum dilution of 1:800 of the anti-34 kDa protein serum.

Results of the indirect plate ELISA for detection of heat killed whole cells of $V$. parahaemolyticus at various dilutions of the anti-34 kDa rabbit antiserum are presented in Table 2. The minimum detection limit for heat killed whole cells of $V$. parahaemolyticus was estimated as $10^{6}$ cells $\mathrm{ml}^{-1}$ (Table 2; Fig. 3) using the anti $34 \mathrm{kDa}$ antiserum at a maximum dilution of $1: 3200$. The cross reaction studies revealed that polyclonal rabbit antiserum directed against $34 \mathrm{kDa}$ cell surface protein was specific for $V$. parahaemolyticus detection. The antiserum gave strong

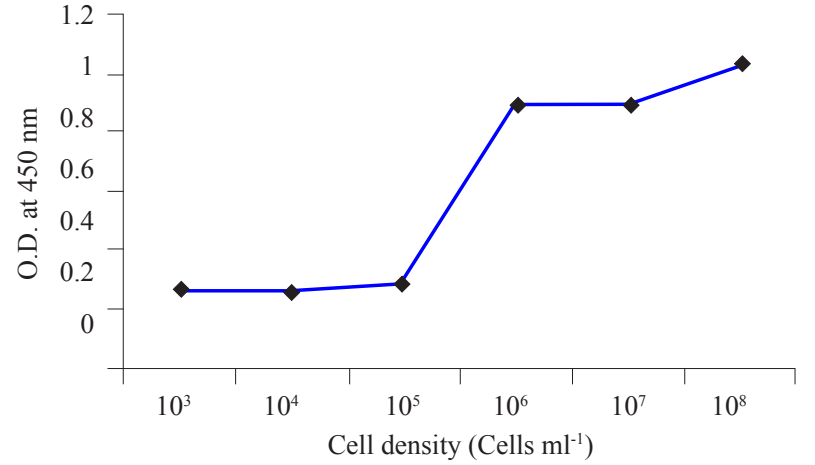

Fig. 3. ELISA titre for different concentrations of heat killed whole cells of $V$. parahaemolyticus by indirect plate ELISA using the antiserum raised against the $34 \mathrm{kDa}$ protein at 1:3200 dilution

positive reaction with all the ten $V$. parahaemolyticus strains, while it gave negative reaction with other Vibrio species tested viz., $V$. vulnificus and $V$. alginolyticus (Table 2).

Table 1. ELISA titres (OD values at $450 \mathrm{~nm}$ ) for different concentrations of crude cell surface proteins of $V$. parahaemolyticus at various dilutions of the antiserum raised against the $34 \mathrm{KDa}$ cell surface protein

\begin{tabular}{lllllll}
\hline \multirow{2}{*}{ Antiserum dilution } & \multicolumn{3}{c}{ Antigen concentration $(\mu \mathrm{g})$} \\
\cline { 2 - 7 } & 100 & 80 & 60 & 40 & 20 & 10 \\
\hline $1: 100$ & 0.983 & 0.903 & 0.677 & 0.957 & 0.991 & 0.957 \\
$1: 200$ & 0.629 & 0.629 & 0.565 & 0.699 & 0.807 & 0.969 \\
$1: 400$ & 0.513 & 0.493 & 0.450 & 0.507 & 0.501 & 0.570 \\
$1: 800$ & 0.389 & 0.380 & 0.383 & 0.416 & 0.460 & 0.431 \\
$1: 1600$ & 0.381 & 0.348 & 0.323 & 0.329 & 0.371 & 0.326 \\
$1: 3200$ & 0.362 & 0.314 & 0.312 & 0.303 & 0.341 & 0.331 \\
$1: 6400$ & 0.266 & 0.253 & 0.241 & 0.257 & 0.232 & 0.236 \\
Control & 0.227 & 0.199 & 0.174 & 0.212 & 0.174 & 0.194 \\
\hline
\end{tabular}

Table 2. ELISA titres (OD values at $450 \mathrm{~nm}$ ) for different concentrations of heat killed whole cells of $V$. parahaemolyticus at various dilutions of the antiserum raised against the $34 \mathrm{KDa}$ cell surface protein. ELISA titres for heat killed whole cells of $V$. vulnificus and $V$. alginolyticus at a cell density of $10^{6}$ cells $\mathrm{ml}^{-1}$ at antiserum dilution of $1: 3200$ are also presented

\begin{tabular}{|c|c|c|c|c|c|c|}
\hline \multirow{2}{*}{ Antiserum dilution } & \multicolumn{6}{|c|}{ Antigen concentration (cells ml ${ }^{-1}$ ) } \\
\hline & $10^{8}$ & $10^{7}$ & $10^{6}$ & $10^{5}$ & $10^{4}$ & $10^{3}$ \\
\hline \multicolumn{7}{|l|}{ V. parahaemolyticus } \\
\hline $1: 100$ & 1.988 & 1.699 & 1.699 & 0.593 & 0.580 & 0.561 \\
\hline $1: 200$ & 1.923 & 1.606 & 1.606 & 0.458 & 0.450 & 0.508 \\
\hline $1: 400$ & 1.765 & 1.473 & 1.473 & 0.427 & 0.351 & 0.415 \\
\hline $1: 800$ & 1.599 & 1.238 & 1.238 & 0.359 & 0.309 & 0.328 \\
\hline $1: 1600$ & 1.177 & 1.026 & 1.026 & 0.305 & 0.268 & 0.284 \\
\hline $1: 3200$ & 1.023 & 0.891 & 0.891 & 0.284 & 0.256 & 0.265 \\
\hline 1:6400 & 0.693 & 0.512 & 0.338 & 0.275 & 0.202 & 0.228 \\
\hline \multicolumn{7}{|l|}{ V. vulnificus } \\
\hline 1:3200 & - & - & 0.411 & - & - & - \\
\hline \multicolumn{7}{|l|}{ V. alginolyticus } \\
\hline 1: 3200 & - & - & 0.331 & - & - & - \\
\hline Control & 0.231 & 0.282 & 0.282 & 0.233 & 0.192 & 0.200 \\
\hline
\end{tabular}




\section{Discussion}

The specificity and to some extent the sensitivity of any immunoassay depends on the quality of the antibodies used in the reagents (Swain et al., 2003; Thuy et al. 2013). Cross reactions due to related antigens can occur, and these can limit the usefulness of the test. Therefore it is necessary to select appropriate antigens for developing immunoassays in order to avoid cross reactions (Swain et al., 2001; Tully et al., 2006).

The phenotypic variability of isolates from the environment and from fish/shellfish makes it difficult to distinguish between $V$. parahaemolyticus and other members of this genus, particularly $V$. alginolyticus, $V$. harveyi and $V$. mimicus accurately by means of biochemical tests (Wachsmuth et al., 1980; Croci et al., 2007). One of the major difficulties in biochemical identification of $V$. parahaemolyticus is the variability in some of the activities, such as fermentation of sugars like sucrose, arabinose and cellobiose (Karunasagar et al., 1997; Tyagi et al., 2009). However, in the present study, only the strains giving typical reactions as per Bauman and Schubert (1984) were considered.

All the test strains and the MTCC reference strain of $V$. parahaemolyticus used for the studies were Kanagawa negative and tested positive for urease production. Most human pathogenic strains of $V$. parahaemolyticus produce a major virulence factor, the thermostable direct hemolysin (tdh) and are designated as Kanagawa phenomenon $\left(\mathrm{KP}^{+}\right)$ positive (Johnson, 2009). Another virulence factor, the tdh-related hemolysin (trh) is generally associated with the Kanagawa phenomenon negative $\left(\mathrm{KP}^{-}\right)$strains or with urease positive strains of $V$. parahaemolyticus (Okuda et al., 1997; Kumar et al., 2011). Though most of the environmental strains of $V$. parahaemolyticus are typically not human pathogens, they cause disease in fish and shellfish (DePaola et al., 2003; Nordstrom and DePaola., 2003; MartinezUrtaza et al., 2006).

Extraction with 1\% SDS was very effective in solubilising the cell surface proteins. Though the procedure involved heating at $70^{\circ} \mathrm{C}$, the bacterial cells remained intact in the procedure. This indicated that only cell surface proteins and not the cytoplasmic proteins were extracted. The extraction of cell-envelope bound protein with SDS was found to be an effective method by previous workers (Chang et al., 1994; Chen and Chang, 1996).

The major protein band of $55 \mathrm{kDa}$ was found to be common in all the three Vibrio species i.e., $V$. parahaemolyticus, $V$. aliginolyticus and $V$. vulnificus. The outer membrane protein pattern of all the V. parahaemolyticus test strains were identical, with 5 to 6 major bands. The $34 \mathrm{kDa}$ protein band which was very prominent in all the $V$. parahaemolyticus test strains was not present in $V$. aliginolyticus and $V$. vulnificus. Hence, this cell surface protein was selected as species-specific antigen for V. parahaemolyticus.

In the present study, the growth conditions and extraction procedures used were identical for all the test strains and all the $V$. parahaemolyticus strains gave similar banding patterns, except for the type strain (MTCC 451) for which the $37 \mathrm{kDa}$ protein band was very distinct as compared to the same of $V$. parahaemolyticus isolates from fish. Chang et al. (1994) identified 3 to 4 major bands having molecular weight in the range $30 \mathrm{kDa}$ to $40 \mathrm{kDa}$ in $V$. parahaemolyticus isolated from seafood. They found that two distinct bands with apparent molecular weights of $36 \mathrm{kDa}$ and $34 \mathrm{kDa}$ were abundant in all the $V$. parahaemolyticus strains. They used these two proteins collectively for immunising rabbits to raise antisera and developed a latex agglutination test for rapid identification of food borne $V$. parahaemolyticus. In the present study too, the $36 \mathrm{kDa}$ protein was recorded in all the $V$. parahaemolyticus strains tested, but it was not as prominent as the $34 \mathrm{kDa}$ protein. Moreover, the $36 \mathrm{kDa}$ protein band was also present in the other species of Vibrio tested viz., $V$. aliginolyticus and $V$. vulnificus.

The $34 \mathrm{kDa}$ cell surface protein of $V$. parahaemolyticus was purified by preparative SDS PAGE and visualised by staining with sodium acetate (Higgins and Dahmus, 1979). This is a rapid and sensitive method for the detection of protein bands in SDS PAGE gels that is suitable for the recovery of individual polypeptides on a preparative scale. The process is reversible and allows for the complete recovery of unmodified protein from preparative gels. The visualisation is rapid, requiring between 60 and $80 \mathrm{~min}$ for $3 \mathrm{~mm}$ gels and sensitive, detecting as little protein as $0.1 \mu \mathrm{g} \mathrm{mm}^{-3}$. In this method high concentrations of sodium acetate (4M) is used to precipitate SDS, not bound to protein. In such gels protein bands are transparent within a white background and are effectively viewed against a dark background. After appropriate visualisation, the band corresponding to the molecular weight $34 \mathrm{kDa}$ was excised with a scalpel and immediately washed thrice in deionised water and used as antigen for immunising rabbit to develop polyclonal antiserum (Sachan and Agarwal, 2002).

Immunisation of rabbits was accomplished by inoculation of protein along with FIA after excising $34 \mathrm{kDa}$ band directly from preparative SDS PAGE gels. This method of immunisation using proteins in PAGE was found to be effective for production of antisera and good titer was obtained after 3 boosters. The extraction of cell surface proteins from $V$. parahaemolyticus with SDS and the excision of the desired bands directly from SDS gels 
are convenient ways to obtain highly purified antigens for immunisation purposes. The procedure eliminates the step of eluting proteins from polyacrylamide gels, thus avoiding further loss of the desired proteins. In addition, polyacrylamide gel can act as an adjuvant (Weintraub and Raymond, 1963) by slowly releasing antigens from the gel. Though animals can produce antibodies against polyacrylamide (Weintraub and Raymond, 1963) this does not cause problems of cross reaction, since the assay systems normally do not contain polyacrylamide. By using this simple technique, antigen purification and animal immunisation could be done within a period of 2 to 3 days. This methodology was also successfully applied to prepare specific antibodies against Staphylococcus aureus (Chang and Ding, 1992); V. parahaemolyticus (Chang et al., 1994; Chen and Chang, 1996) and Listeria monocytogenes (Chen and Cheng, 1996).

ELISA techniques are widely used for detection of pathogenic Vibrio species in aquaculture (Robertson et al., 1998; De Pinto et al., 2012). In the indirect plate ELISA test developed for rapid detection of fish pathogenic $V$. parahaemolyticus using the anti-34 $\mathrm{kDa}$ protein serum, even the lowest concentration $(10 \mu \mathrm{g})$ of the cell surface protein tested, gave positive reaction. The minimum detection limit for heat killed whole cells of $V$. parahaemolyticus was estimated as $10^{6}$ cells $\mathrm{ml}^{-1}$ using the anti-34 $\mathrm{kDa}$ antiserum at a maximum dilution of 1: 3200. Sensitivity of the indirect ELISA enabled to understand cross reaction between closely related OMP proteins unlike agglutination test (Kumar et al., 2010). These findings are in agreement with other ELISA systems, where optimum reaction at a cell concentration of $10^{6}$ cells $\mathrm{ml}^{-1}$ was achieved (Sachan et al., 2002 ). The cross reaction studies revealed that polyclonal rabbit antiserum directed against $34 \mathrm{kDa}$ cell surface protein was specific for $V$. parahaemolyticus detection. The antiserum gave strong positive reaction with all the ten $V$. parahaemolyticus strains, while it gave negative reaction with other Vibrio species tested viz., V. vulnificus and $V$. alginolyticus (Table 2).

The use of cell wall antigens to develop immunological methods for the rapid detection of bacteria has also been advocated by other researchers (Gharaibeh Dima et al., 2013). ELISA techniques are widely used immunodiagnostic techniques to detect pathogens in culture systems (Romestand et al., 1993; Kumar et al., 2011) due to its sensitivity. In the latex agglutination test for the rapid identification of V. parahaemolyticus (Chang et al., 1994), two bacterial outer membrane proteins, with molecular weights of $36 \mathrm{kDa}$ and $34 \mathrm{kDa}$ were used as antigens for producing polyclonal antibodies. However, in their study, some strains of vibrios belonging to the species viz., $V$. alginolyticus, $V$. harveyi and $V$. mimicus produced false positive results. From the present study it is obvious that the $36 \mathrm{kDa}$ protein is also present in $V$. alginolyticus and this could be the reason for the cross reaction observed with this particular species using the latex agglutination test.

In the sandwich ELISA developed for rapid detection of V.parahaemolyticus in foods (Chen and Chang, 1995), the detection limit for total outer membrane proteins of $V$. parahaemolyticus was $10 \mathrm{ng} \mathrm{ml}^{-1}$. Their study indicated that the $36 \mathrm{kDa}$ and $34 \mathrm{kDa}$ outer membrane proteins are common antigens of $V$. parahaemolyticus. They have recommended ELISA technique for rapid screening of $V$. parahaemolyticus in foods which can be finished within $24 \mathrm{~h}(18 \mathrm{~h}$ of growth in enrichment broth and $4 \mathrm{~h}$ for ELISA). However, cross reactions were still observed with several other Vibrio species viz., V. tubiashi, $V$. campbelli and $V$. vulnificus. From the results of the present study, it is evident that the cross reaction with $V$. vulnificus could be due to the sharing of the $36 \mathrm{kDa}$ outer membrane protein.

The results of the present study have clearly shown that the $34 \mathrm{kDa}$ fractioned antigen from the cell surface proteins of $V$. parahaemolyticus, having no apparent cross reactive components with related bacterial antigens, can be exploited for diagnostic purposes. The antiserum raised against the $34 \mathrm{kDa}$ protein gave strong positive reaction with all the ten $V$. parahaemolyticus strains tested and negative reactions against two other common Vibrio species associated with vibriosis in groupers viz., $V$. vulnificus and $V$. alginolyticus. The possibility of cross reaction with other closely related vibrios such as $V$. harveyi, V. mimicus, and $V$. campelli needs to be further evaluated. However, the high titre of the antiserum indicates possibility of elimination of any cross reactions with other taxa, while giving positive reactions with the majority of $V$. parahaemolyticus strains. Castro et al. (1995) have shown that cross reaction can be minimised using higher dilution of antiserum. The detection technique can be made more sensitive by developing immunocapture (sandwitch) ELISA using antibodies against crude cell surface proteins/killed whole cells as capture antibodies and the anti-34 $\mathrm{kDa}$ antiserum as tracing antibody. There is also scope for developing dot ELISA technique using the anti-34 $\mathrm{kDa}$ antiserum for rapid diagnosis of $V$. parahaemolyticus without the need for sophisticated equipment.

The findings from the present investigation may be used as baseline information for designing rapid, sensitive and cost-effective immunodiagnostic kits for important fish bacterial pathogens, which can help in timely diagnosis of diseases and in adopting more scientific health management measures in aquaculture. Compared with the conventional identification procedures, requiring 
a battery of physiological and morphological tests, the proposed identification method is simple and time saving.

\section{Acknowledgements}

The authors wish to express their gratitude to the Director, ICAR-Central Marine Fisheries Research Institute for providing necessary facilities for carrying out this research work. The financial support in the form of a junior research fellowship awarded to the senior author by the Indian Council of Agricultural Research (ICAR), New Delhi during the period of the study is gratefully acknowledged.

\section{References}

Austin, B. and Austin, D. A. 2007. Bacterial fish pathogens: Diseases of farmed and wild fish, $4^{\text {th }}$ edn. Chichester, UK: Praxis Publishing Ltd., 594 pp.

Bauman, P. and Schubert, R. H. W. 1984. Family II. Vibrionaceae In: Kreig, N. R. (Ed.), Bergey's manual of systematic bacteriology, vol.1, The Williams and Wilkins Co., Baltimore, p. 516-538.

Bhunia, A. and Johnson, M. G. 1992. Monoclonal antibody specific for Listeria monocytogenes associated with a 66-kilodalton cell surface antigen. Appl. Environ. Microbiol., 58: 1924-1929.

Castro, D., Luque, A., Santamaria, J. A., Maes, P., Martinez, M. E. and Borrego, J. J. 1995. Development of immunological techniques for the detection of the causative agent of the brown ring disease. Aquaculture, 132: 97-104.

Chang, T. C. and Ding, H. C. 1992. Rapid detection of Staphylococcus aureus in food by flow cytometry. J. Rapid Method Autom. Microbiol., 1: 133-147.

Chang, T. C., Chen, C. H. and Chen, H. C. 1994. A latex agglutination test for the rapid identification of Vibrio parahaemolyticus. J. Food Protect., 57: 31-36.

Chen, C. H. and Chang, T. C. 1995. An enzyme-linked immunosorbent assay for the rapid detection of Vibrio parahaemolyticus. J. Food Protect., 58: 873-878.

Chen, H. C. and Chang, T. C. 1996. Rapid detection of Vibrio parahaemolyticus in oysters by immunofluorescence microscopy. Int. J. Food Microbiol., 29: 311-319.

Chen, S. C. and Chang, T. C. 1996. Identification of Listeria monocytogenes based on the detection of 68 kilodalton cell surface antigen. J. Food Protect., 59: 1176-1181.

Chi, X. C., Wong, J., Yan, Q. P. and Su, Y. Q. 2007. Preparation and applications of monoclonal antibody against the pathogenic Vibrio parahaemolyticus from Pseudosciaena crocea. Mar. Sci., 31: 1-5.

Croci, L., Suffredini, E., Cozzi, L., Toti, L., Ottavini, D., Pruzzo, C., Serratore, P., Fischetti, R., Goffredo, E., Loffredo, G. and Mioni, R. 2007. Comparison of different biochemical and molecular methods for the identification of Vibrio parahaemolyticus. J. Appl. Microbiol., 102: 229-237.

Crosby, N. T. 1967. The identification of nitrite in water using Cleve's acid, 1- naphthylamine-7- sulphonic acid. Proc. Soc. Water Treatment Exp., 16: 51-55.

Danayadol, Y. 1999. Diseases of grouper (Epinephelus coioides) cultured in Thailand. In: Hat Yai, (Ed.), Proceedings of the APEC/NACA Workshop on Grouper Research and Development, 7-9 April 1999, Thailand.

DePaola, A., Ulaszek, J. and Kaysner, C. A. 2003. Molecular, serological and virulence characteristics of Vibrio parahaemolyticus isolated from environmental, food and clinical sources in North America and Asia. Appl. Environ. Microbiol., 69: 3999-4005.

Di Pinto, A., Terio, V., Di Pinto, P., Colao, V. and Tantillo, G. 2012. Detection of Vibrio parahaemolyticus in shellfish using polymerase chain reaction-enzyme-linked immunosorbent assay. Lett. Appl. Microbiol., 54(6): 494-498.

Diasda, S. W. and Tambourgi, D. V. 2010. IgY. A promising antibody for use in immunodiagnostic and in immunotherapy. Vet. Immunol. Immunopathol., 135: 173-18.

Do, T. H., Tran, V. H., Nguyen, T. T. G., Phan V. U. and Nguyen, T. N. H. 2008. Common diseases in marine fish in Khanh Hoa, Vietnam. Fisheries Sci.Technol., 16: 24-35.

Fofstra, R. and DanKert, J. 1979. Antigenic cross reactivity of major outer membrane proteins in Enterobacteriaceae species. J. General Microbiol., 111: 293-302.

Gharaibeh Dima, N., Biel Frances, M. and Hase, Claudia, C. 2013 Development of monoclonal antibody-based assays for the detection of Vibrio tubiashii zinc-metalloprotease (VtpA). J. Microbiol. Meth., doi:10.1016/j.mimet.2013.05.009.

Harikrishnan, R., Balasundaram, C. and Heo, M. S. 2010 Molecular studies, disease status and prophylactic measures in grouper aquaculture: Economic importance, diseases and immunology. Aquaculture, 309: 1-14.

Harikrishnan, R., Balasundaram, C. and Heo, M. S. 2011 Fish health aspects in grouper aquaculture. Aquaculture, 320: $1-21$.

Higgins, R. C. and Dahmus, M. E. 1979. Rapid visualisation of protein bands in preparative SDS-polyacrylamide gels. Analyt. Biochem., 93: 257-260.

Holding, A. J. and Collee, J. G. 1971. Routine biochemical tests. In: Norris, J. R. and Robbins, D. W. (Eds.), Methods in microbiology, 6A Academic Press, London, 32 pp.

Inoue, T., Matsuzaki, S., Tanaka, S. A. 1995. 26-kDa outer membrane protein, OmpK, common to Vibrio species is the receptor for a broad-host-range vibriophage, KVP40. FEMS Microbiol. Lett., 125: 101-115.

Johnson, C. N. 2009. Genetic relatedness among $t d h+$ and $t r h+$ Vibrio parahaemolyticus cultured from Gulf of Mexico oysters (Crassostrea virginica) and surrounding water and sediment. Microb. Ecol., 57: 437-443. 
Kabir, S. 1986. Composition and immunological properties of cell surface proteins of Vibrio cholera. J. General Microbiol., 132: 2235-2242.

Karunasagar, I., Nayak, B. B. and Karunasagar, I. 1997. Rapid detection of Vibrio parahaemolyticus from fish by polymerase chain reaction (PCR). In: Flegel, T. W. and MacRae, I. H. (Eds.), Diseases in Asian Aquaculture III. Fish Health Section, Asian Fisheries Society, Manila, p. $119-122$.

Krupesha Sharma, S. R., Rathore, G., Verma, D. K., Sadhu, N. and Philipose, K. K. 2012. Vibrio alginolyticus infection in Asian seabass (Lates calcarifer, Bloch) reared in open sea floating cages in India. Aquac. Res., 44: 86-92.

Kumar, B. K., Raghunath, P., Devegowda, D., Deekshit, V. K., Venugopal, M. N., Karunasagar, I. and Karunasagar, I. 2011. Development of monoclonal antibody based sandwich ELISA for the rapid detection of pathogenic Vibrio parahaemolyticus in seafood. Int. J. Food. Microbiol., 145: 244-249.

Kumar, G., Rathore. G., Sengupta. U., Kapoor, D. and Lakra, W. S 2010. Production of monoclonal antibodies specific to major outer membrane protein of Edwardsiella tarda. Comp. Immunol. Microbiol. Infect. Dis., 33: 133-144.

Kumar, S. R., Parameswaran, V., Ahmed, V., Musthaq, S. S. and Hameed, A. 2007. Protective efficiency of DNA vaccination in Asian seabass (Lates calcarifer) against Vibrio anguillarum. Fish Shellfish Immunol., 23: 316-326.

Laemmli, U. K. 1970. Cleavage of structural proteins during the assembly of the head of bacteriophage T4. Nature, 227: $680-685$

Lee, J. V., Hundrie, M. S. and Shewan, J. M., 1979. Identification of Aeromonas, Vibrio and related organisms. In: Skinner, F. A. and Lovestock, D. W. (Eds.), Identification methods for microbiologists. Society for Applied Microbiology, Technical Series No. 14. Academic Press, London, p. 51-156.

Li, N., Yang, Z., Bai, J., Fu, X., Liu, L., Shi, C. and Wu, S. 2010. A shared antigen among Vibrio species: Outer membrane protein-OmpK as a versatile vibriosis vaccine candidate in orange-spotted grouper (Epinephelus coioides). Fish Shellfish Immunol., 28: 952-956.

Liao, I. C., Huang, T. S., Tsai, W. S., Hsueh, C. M., Chang, S. L. and Leano, E. M. 2004. Cobia culture in Taiwan: Current status and problems. Aquaculture, 237: 155-165.

Lowry, O. H., Rosebrough, N. J., Farr, A. L. and Randall, R. J. 1951. Protein measurement with phenol reagent. J. Biological Chem., 193: 256-275.

Mac Faddin, J. F. 1980. Biochemical. tests for identification of medical bacteria, $2^{\text {nd }}$ edn. The Williams and Wilkins Co., Baltimore, p. 36-318.

Manning, D. A., Imbesi, F. and Haynes, D. R. 1982. Cell envelope proteins in Vibrio cholerae. FEMS Microbiol. Lett., 14: 159-166.
Mao, Z., Yu, L., You, Z., Wei, Y. and Liu, Y. 2007. Cloning, expression and immunogenicty analysis of five outer membrane proteins of Vibrio parahaemolyticus. Fish Shellfish Immunol., 23: 567-57.

Martinez-Urtaza, J., Lozano-Leon, A., Vina-Feas, A., de Novoa, J. and Garcia-Martin, O. 2006. Differences in the API $20 \mathrm{E}$ biochemical patterns of clinical and environmental Vibrio parahaemolyticus isolates. FEMS Microbiol. Lett., 255: 75-81.

Najiah, M., Lee, K. L., Hassan, M. D., Sharief, M. and Mohd-Azmi, M. L. 2003. Preliminary study on genetic distance of Vibrio parahaemolyticus isolate from diseased fish and shrimp brackfishwater ponds by Random Amplified Polymorphic DNA (RAPD) in Malaysia. Asian Fish. Sci., 16: 299-305.

Ningqiu, L., Junjie, B., Shuqin, W., Xiaozhe, F., Haihua, L. and Xing, Y. 2008. An outer membrane protein, OmpK, is an effective vaccine candidate for Vibrio harveyi in orangespotted grouper Epinephelus coioides. Fish Shellfish Immunol., 25: 829-833.

Nordstrom, J. L. and DePaola, A. 2003. Improved recovery of pathogenic Vibrio parahaemolyticus from oysters using colony hybridisation following enrichment. J. Microbiol. Methods, 52: 273-277.

Nguyen, T. T. T. and Nguyen, H. D. 2008. Ulcerative disease in cultured grouper in Khanh Hoa province, Vietnam. Aquac. Asia Pacific, 4: 27-29.

Okuda, J., Ishibashi, M., Abbott, S. L., Janda, J. M. and Nishibuchi, M. 1997. Analysis of the thermostable direct hemolysin (tdh) gene and the tdh-related hemolysin (trh) genes in urease- positive strains of Vibrio parahaemolyticus isolated on the west coast of the United States. J. Clinical Microbiol., 35: 1965-1971.

Paik, G. 1980. Reagents, stains and miscellaneous test procedures. In: Lennette, E. H., Balows, A., Hausler, W. J. and Traunt, J. P. (Eds.), Manual of clinical microbiology, $3^{\text {rd }}$ edn. American Society for Microbiology, Washington DC, p. 1000-1024.

Qian, R. H., Xiao, Z. H., Zhang C. W., Chu W. Y., Wang L. S. and Zhou H. H. 2008. A conserved outer membrane protein as an effective vaccine candidate from Vibrio alginolyticus. Aquaculture, 278: 50-60.

Robertson, P. A. W., Xu, H. S. and Austin, B. 1998. An enzymelinked immunosorbent assay (ELISA) for the detection of Vibrio harveyi in penaeid shrimp and water. J. Microbiol. Methods, 34(1): 31-39.

Romestand, D., Breuil Costie, F. and Bouix, G. 1993. An ELISA technique for rapid diagnosis of vibriosis in seabass Dicentrarchus labrax. Dis. Aquat. Org., 15: 137-141.

Rosec, J. P., Marie, S., Veronique, C. and Mireille, B. 2009. Detection of total and pathogenic Vibrio parahaemolyticus in shellfish: Comparison of PCR protocols using pR72H or toxR targets with a culture method. Int. J. Food Microbiol., 129: 136-145. 
Sachan, N. and Agarwal, R. K. 2002. A simple enzyme-linked immunosorbent assay for the detection of Aeromonas spp. Veterinarski Arhiv., 72(6): 327-334.

Seltman, G. and Holst, O. 2002. The bacterial cell wall. Springer-Verlag, Berlin, Heidelberg and New York, p. 9-102.

Smith, H. L. and Goodner, 1958. Detection of bacterial gelatinases by gelatin-agar plate methods. J. Bacteriol., 76: 662-665.

Sobhana, K. S. 2009. Diseases of seabass in cage culture and control measures. In: Imelda Joseph, Edwin, V. Joseph and Susmitha, V. (Eds.), Course manual: National training on cage culture of seabass. Central Marine Fisheries Research Institute, Kochi and National Fisheries Development Board, Hyderabad, India. p. 87-93.

Sudheesh, P. S. and Xu H. S. 2001. Pathogenecity of Vibrio parahaemolyticus in tiger prawn Penaeus monodon Fabricius: possible role of extracellular protease. Aquaculture, 196: 37- 46 .

Swain, P., Mukherjee, S. C., Sahoo, P. K., Das, B. K., Pattnaik, P., Murjani, G. and Nayak, S. K. 2001. Dot-enzyme linked immunosorbent assay (Dot-ELISA for the diagnosis of Edwardsiella tarda infection in fish. Asian Fish. Sci., 14: 89-93.

Swain, P. and Nayak, S. K. 2003. Comparative sensitivity of different serological tests for seromonitoring and surveillance of Edwardsiella tarda infection of Indian major carps. Fish Shellfish Immunol., 15(4): 333-340.

Thuy, N. T. T., Nguyen, D. H. and Wergel, H. I.2013. Specific humoral immune response and protection against Vibrio parahaemolyticus in orange spotted grouper Epinephelus coioides. Int. J. Aquatic Sci., 4(1): 24-35.

Tully, E., Hearty, S., Leonard, P. and O'Kennedy, R. 2006. The development of rapid fluorescence-based immunoassays, using quantum dot-labelled antibodies for the detection of Listeria monocytogenes cell surface proteins. Int. J. Biol. Macromol., 139(1-3): 127-34.

Tyagi, A., Saravanan, V. and Karunasagar, I. 2009. Detection of Vibrio parahaemolyticus in tropical shellfish by SYBR 178 green real-time PCR and evaluation of three enrichment media. Int. J. Food Microbiol., 129: 124-130.

Wachsmuth, I. K., Morris, G. K. and Feely, J. C. 1980. Vibrio In: Traunt (Ed.), Manual of clinical microbiology. American Society for Microbiology, Washington, DC, p. 226-234.

Wagatsuma, S. 1967. On a medium to test the hemolytic reaction of Vibrio parahaemolyticus. Media Circle, 3: 159-162.

Weintraub, M. and Raymond, S. 1963. Antiserums prepared with acrylamide gel used as adjuvant. Science, 142: 1677-1678.

West, P. A. and Colwell, R. R. 1984. Identification and classification of vibrionaceae - an overview. In: Colwell, R. R. (Ed.), Vibriosis in the environment. John Willey and Sons, New York, p. 285-363. 